551. 510. 7

\title{
On the Radioactivity and Particle Analysis of Airborne Dust in the Troposphere
}

\author{
by \\ N. Yano and H. Naruse \\ Meteorological Research Institute, Tokyo
}

(Received April 8, 1960)

\section{Introduction}

It is now well known from earlier works (JMA, 1959), (STEwART, 1957) that artificial radioactive fallout produced by thermonuclear weapons tests is remarkably effected by various meteorological elements such as precipitation, vertical mixing etc. during its passage from the stratosphere into the troposphere. The purpose of the present study is to investigate the radioactivity and properties of these fallout materials in the troposphere.

Aircraft observations of up to a total of 28 times were made on the day of October 15, 1957 and in the period from December, 1958 to March, 1959. Of these observations four were made at successive height from ground up to a height of $7,000 \mathrm{~m}$ and the remning twenty-four were carried out on the flight path of regular service. The days of the observations were selected so that on these days no nuclear explosion was seen in any part of the globe. This selection was made in order to carry out our observation during stratospheric fallout.

As the result of the present research, we can show: (1) the technical problems involved in the method of sampling in the upper atmosphere and the method of measurement, (2) the vertical distribution of the gross activity and detection of nucleids. (3) the vertical concentration of airborne dust, its size distribution, at each height and its composition.

In addition to the results, we shall discuss the relationship between the radioactivity and the airborne dust particles.

\section{Apparatus, method and collection efficiency}

As we mentioned above, the aircraft observations are classified into two groups, i.e. the vertical and the horizontal. The former were made on the horizontal flights taking a trianglular course at each altitude over the Tokyo area and the second were made at a constant height on either Tokyo-to-Sapporo or Tokyo-to-Osaka line.

In order to make this observation, measuring apparatus and dust collectors were set within the body of the aircraft. The equipment for this is shown in Fig. 1. Sampling air runs into the dust collector through the duct and passes out into the atmosphere. The instantaneous flowmeter $\left(\mathrm{M}, \mathrm{M}^{\prime}\right)$ and integrate flowmeter are connected with this duct. The watch $(\mathrm{W})$, thermister for air temperature $(T)$,register of integrate flowmeter $(F)$, pressure gauge $(P)$ and voltmeters $\left(V_{1}, V_{2}\right)$ are set on the same meter board. As to power supply, a dynamo within the body provides DC 24 volts and transforms it into 


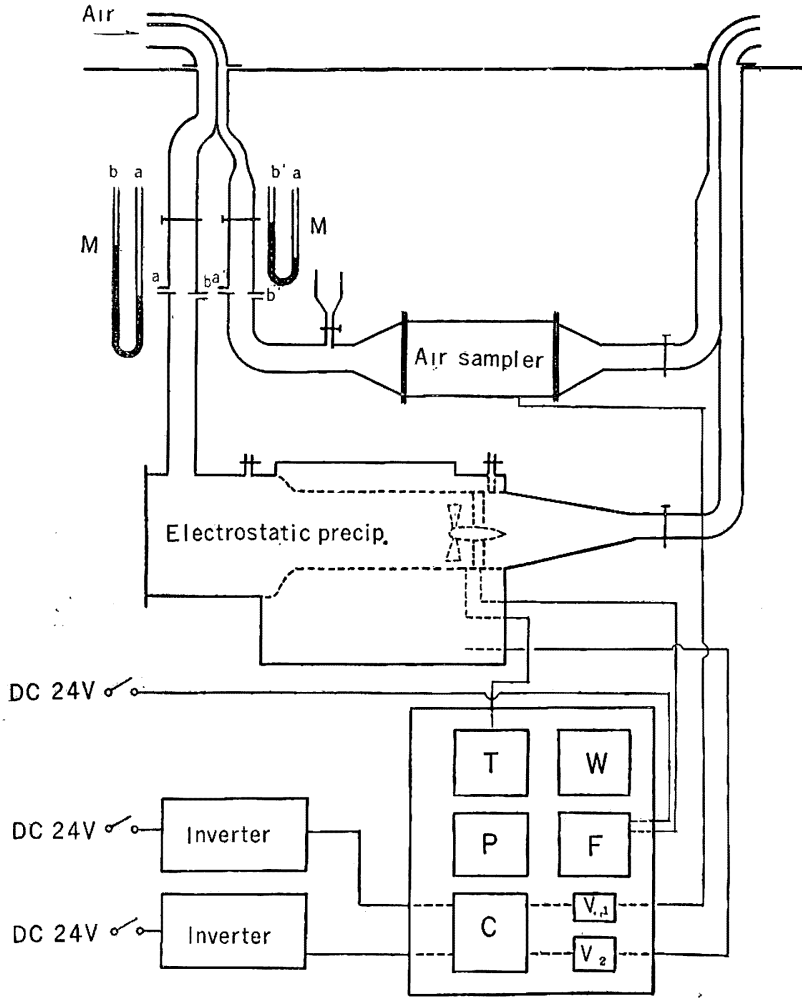

Fig. 1. Equipment for aircraft observation.
$\mathrm{AC} 100 \mathrm{~V}$ by an inverter.

The analytical procedure for radioactivity and dust particles are shown in Fig. 2. The electrostatic precipitator and air sampler were used for collection of airborne dust. The radioactivity of the collected amples were measured by $\beta$-counter after the natural radioactivity diminished. Gamma-spectrum analysis was carried out for samples which have a relatively high activity, after leaving them as they are for about six months. On the other hand, we make arrangement so as to be able to collect electron microscopic samples from the plate of the electrostatic precipitator. These samples were analysed by electron microscope. Samples obtained from the impactor were used for analysis of the particle concentration at each height. The concentration was determined by optical microscope for relatively largesize particles, i. e. larger than $4 \mu$ in diameter.

COLLECTOR

RADIOACTIVITY

PARTICLE

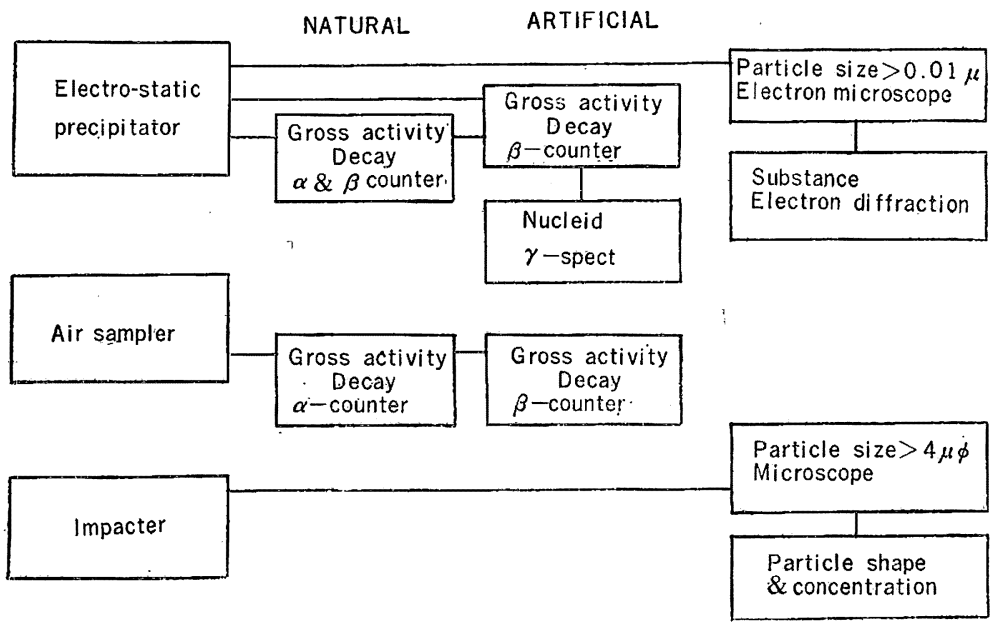

Fig. 2. Analytical procedure of radioactivity and air-borne dust. 
It will be necessary to look into the relation between the pressure and the collection efficiency of the electrostatic precipitator. Two different types of collectors are used for this purpose. The details of these two collectors are shown in Table 1, from which

Table 1.

\begin{tabular}{lccc}
\hline \hline Type of air sampler & Flow rate & & Efficiency \\
\hline $\begin{array}{l}\text { Filter paper method } \\
\quad \text { (Air sampler) }\end{array}$ & $200 \mathrm{l} / \mathrm{min}$ & Wattman No. 41, 150 $\mathrm{W}$ & $80 \%$ \\
Electrostatic method & $1000 \mathrm{l} / \mathrm{min}$ & $12-7 \mathrm{KV}, 2 \mathrm{~mA}$ & $90-50 \%$ \\
\hline
\end{tabular}

we found that the electrostatic precipitator has a high flow rate, but its efficiency changes with the atmospheric pressure. Thus an attempt is made to correct departure due to the pressure by adopting the filter paper method, which makes use of Wattman No. 41 as a standard.

The efficiency of this plate type precipitator is in general given by the following equation (1), (Rose AND WoOD, 1956).

$$
\varepsilon=1-\exp \left(\frac{x \omega}{v D}\right)
$$

where $\omega$ is the drift velocity of a particle in the direction of electric field, $D$ is the distance between plate and corrona wire, $x$ is the length of the plate measured along the direction of air flow and $v$ is the velocity of particles in the direction of air flow. $x$ and $D$ will be determined by the geometry of positive and negative electrodes. Either can be regarded as a constant value if the constancy of flow rate holds. But $\omega$ is variable and is given by the following equation (2).

$$
\omega=\frac{q E}{6 \pi \eta r},
$$

where $q$ is the charge of a particle, $E$ is the field strength, $r$ is the particle radius and $\eta$ is the viscosity of air. The equation (2) shows that the drift velocity is a function of $q E$ if $r$ and $\eta$ are regarded as constant.

The available upper limit of field strength $E$ is determined by the starting voltage in spark discharge. This tells us that the field strength $E$ will be in proportion to atmospheric pressure. It is considered that the corrona discharge current holds an almost constant value by the pressure effect as far all heights reached here, so that the efficiency (1) may be in proportion to atmospheric pressure (Rose et al, 1956). In fact, plots of the ratio of two different measured values of radioactivity for the pressure are given in Fig. 3, which is a slightly scattered diagram due to large errors in the filter method. But it will be found from Fig. 3 that the proportionality to atmospheric

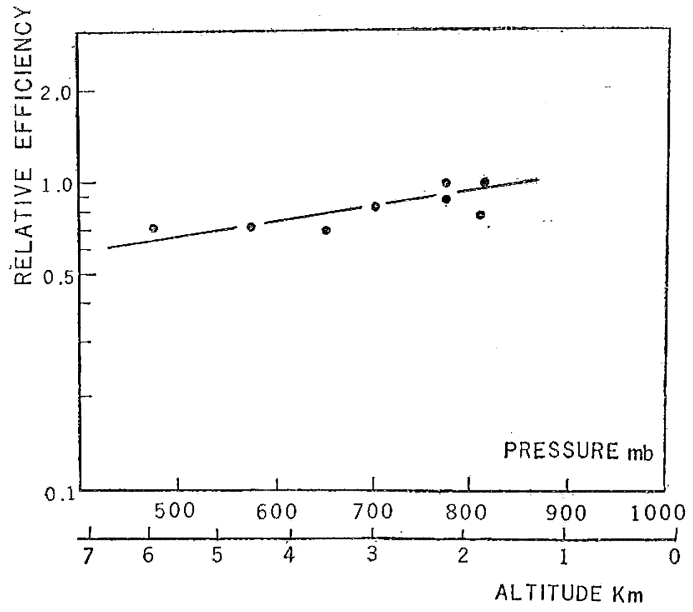

Fig. 3. Relative efficiency of electrostatic precipitator. 
Table 2 .

\begin{tabular}{|c|c|c|c|c|c|c|}
\hline & \multicolumn{2}{|l|}{ Date } & \multirow{2}{*}{$\begin{array}{c}\text { Height } \\
\text { m }\end{array}$} & \multirow{2}{*}{$\begin{array}{c}\begin{array}{c}\text { Volume } \\
\mathrm{m}^{3}\end{array} \\
313.2\end{array}$} & \multirow{2}{*}{$\begin{array}{c}\begin{array}{c}\text { Total } \\
\text { activity } \\
\text { cpm }\end{array} \\
45.48\end{array}$} & \multirow{2}{*}{$\begin{array}{l}\text { Activity } \\
\mu \mu \mathrm{C} / \mathrm{kg} \text { of air } \\
0.97\end{array}$} \\
\hline 1957 & Oct. & $15 *$ & & & & \\
\hline \multirow{3}{*}{1958} & Oct. & $15^{*}$ & 4500 & 329.4 & 55.55 & 1.38 \\
\hline & Dec. & 23 & 1800 & \multirow{2}{*}{44.0} & \multirow{2}{*}{22.50} & \multirow{2}{*}{0.96} \\
\hline & Dec. & 24 & 2500 & & & \\
\hline \multirow[t]{42}{*}{1959} & Jan. & 15 & 1200 & 56.4 & 67.90 & 2.09 \\
\hline & Jan. & 16 & 1500 & 45.8 & 59.85 & 2.35 \\
\hline & Jan. & 20 & 2200 & 128.1 & 177.49 & 2.65 \\
\hline & Jan. & 20 & 2800 & 59.9 & 85.77 & 2.91 \\
\hline & Jan. & 28 & 2600 & 258.7 & 131.58 & 1.02 \\
\hline & Jan. & 28 & 2500 & 258.7 & 131.58 & 1.02 \\
\hline & Jan. & 29 & 1850 & 79.0 & 77.76 & 1.85 \\
\hline & Jan. & 31 & 2200 & 46.9 & 37.00 & 1.56 \\
\hline & Feb. & 10 & 2400 & \multirow{2}{*}{246.2} & \multirow{2}{*}{380.93} & \multirow{2}{*}{3.05} \\
\hline & Feb. & 10 & 2800 & & & \\
\hline & Feb. & 11 & 2200 & 52.6 & 60.88 & 2.19 \\
\hline & Feb. & 13 & 2200 & 55.3 & 52.83 & 1.83 \\
\hline & Feb. & 25 & 2100 & - & - & - \\
\hline & Feb. & 27 & 2200 & 38.4 & 24.10 & 1.20 \\
\hline & Mar. & 2 & 2000 & \multirow{2}{*}{346.7} & \multirow{2}{*}{227.93} & \multirow{2}{*}{1.97} \\
\hline & Mar. & 2 & 2400 & & & \\
\hline & Mar. & 3 & 1800 & 67.9 & 99.36 & 2.75 \\
\hline & Mar. & 4 & 1800 & 44.0 & 62.26 & 2.60 \\
\hline & Mar. & 14 & 2400 & 31.3 & 29.33 & 1.85 \\
\hline & Mar. & 15 & 2000 & 58.1 & 94.73 & 3.39 \\
\hline & Mar. & 19 & 2000 & \multirow{2}{*}{427.7} & \multirow{2}{*}{360.80} & \multirow{2}{*}{2.56} \\
\hline & Mar. & 19 & 2000 & & & \\
\hline & Mar. & $26 \%$ & 3600 & 39.2 & 46.70 & 2.57 \\
\hline & Mar. & $26^{*}$ & 4590 & 33.8 & 79.24 & 5.52 \\
\hline & Mar. & $26^{*}$ & 5970 & 36.9 & 69.73 & 5.08 \\
\hline & Mar. & $27 *$ & 7050 & 56.7 & 213.30 & 11.42 \\
\hline & May & 28 & 2500 & 215.8 & 87.14 & 0.79 \\
\hline & May & 28 & \multirow{2}{*}{2000} & \multirow{2}{*}{62.2} & 30.93 & 0.94 \\
\hline & May & 29 & & & & \\
\hline & May & 30 & 2000 & 54.7 & 36.40 & 1.25 \\
\hline & Jun. & 24 & 2000 & 203.0 & 56.13 & 0.52 \\
\hline & Jul. & 14 & 2000 & 60.4 & 3.13 & 0.10 \\
\hline & Jul. & 15 & 3000 & 52.6 & 7.83 & 0.31 \\
\hline & Aug. & 27 & 2500 & 156.1 & 3.94 & 0.05 \\
\hline & Sep. & 30 & 2500 & 240.9 & 8.03 & 0.06 \\
\hline & Oct. & 20 & 2500 & 199.3 & 7.27 & 0.07 \\
\hline & & 30 & & & & \\
\hline & Nov. & 26 & 2500 & 221.5 & 27.10 & 0.23 \\
\hline & & 27 & & & & \\
\hline & Dec. & $7^{*}$ & 7000 & 39.15 & 7.00 & 1.41 \\
\hline & Dec. & $7 *$ & 5500 & 41.85 & 7.02 & 1.06 \\
\hline & Dec. & $7^{*}$ & 4500 & 43.20 & 3.20 & 0.76 \\
\hline 1960 & Jan. & 19 & 3000 & 73.7 & 2.05 & 0.06 \\
\hline & Feb. & 20 & 2000 & 96.3 & 4.29 & 0.09 \\
\hline
\end{tabular}

*vertical observation 
pressure may hold in general. A correction for relative efficiency, therefore, can be done for the filter paper (Wattman No. 41) by the multiplication of coefficients determined by the solid line in Fig. 3 .

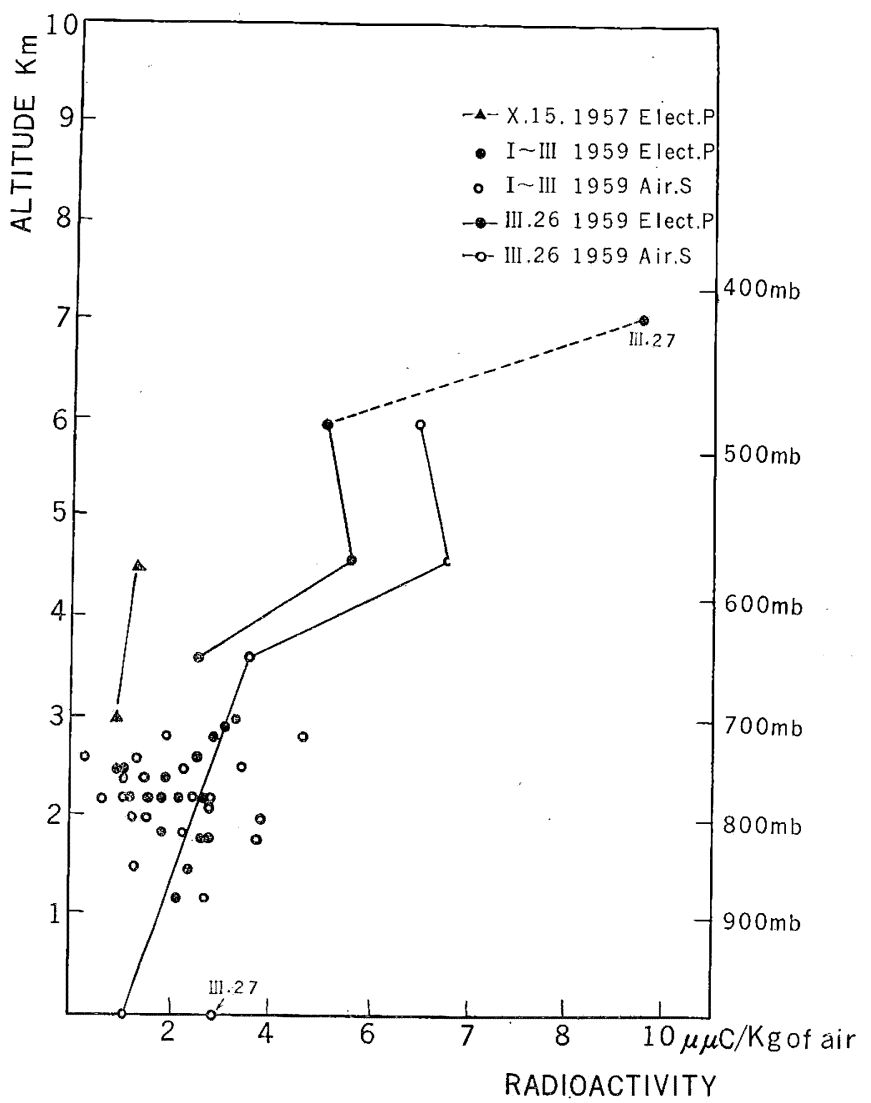

Fig. 4. Vertical distribution of the radioactivity.

\section{Results}

a) Analysis of artificial radioactivity.

The results of the recent observation are given in Table 2. Relations bet ween altitude and radioactivity are illustrated in Fig. 4 , where abscissas indicate radioactivity per $1 \mathrm{~kg}$ of air with the unit of $\mu \mu C$ and ordinates express altitude. In spite of no corrections for efficiency, Fig. 4 tells us that the radioactivity increases exponentially with altitude. The observational values obtained at each height on the same day are indicated by dots connected by solid lines in this figure. The dashed line up to $7050 \mathrm{~m}$ was drawn for the reason that the observation obtained at this height was made on the day following all the other observations. It is also

found that a relatively large number of solid circles which are observed by the regular service at $2000 \sim 3000 \mathrm{~m}$ height are considerably scattered $2 \mu \mu \mathrm{C} / \mathrm{kg}$ of air, but Fig. 5 shows a fairly good agreement between the time variation of these solid circles and the radioactivity of airborne dust near the ground at Tokyo for the same period.

Gamma-spectrum analysis was made for samples which have a relatively high radioactivity on October 1 and 2, 1959 after waiting about six months for the decay of nucleids having short life-time. It seems possible that after a year from nuclear explosion, the remaining nucleids may be $\mathrm{Be}^{137}, \mathrm{Rh}^{106}, \mathrm{Zr}^{95}, \mathrm{Ce}^{144}, \mathrm{Pr}^{144}$. The results of analysis for these nucleids are given in Fig. 6. In this figure, abscissas indicate the energy of gamma-ray and ordinates the total count for 1,048 minutes. Samples on the different dates of March 19, March 27 and February 10, 1959 were obtained under the same circumstances, so that the lower shaded portion in this figure shows the net count which means the total count minus background. All these samples in three cases have two peaks at about 0.5 and $0.75 \mathrm{MeV}$. These peaks may be caused respectively by $\mathrm{Rh}^{106}$ and $\mathrm{Zr}^{95}-\mathrm{Nb}^{95}$. 


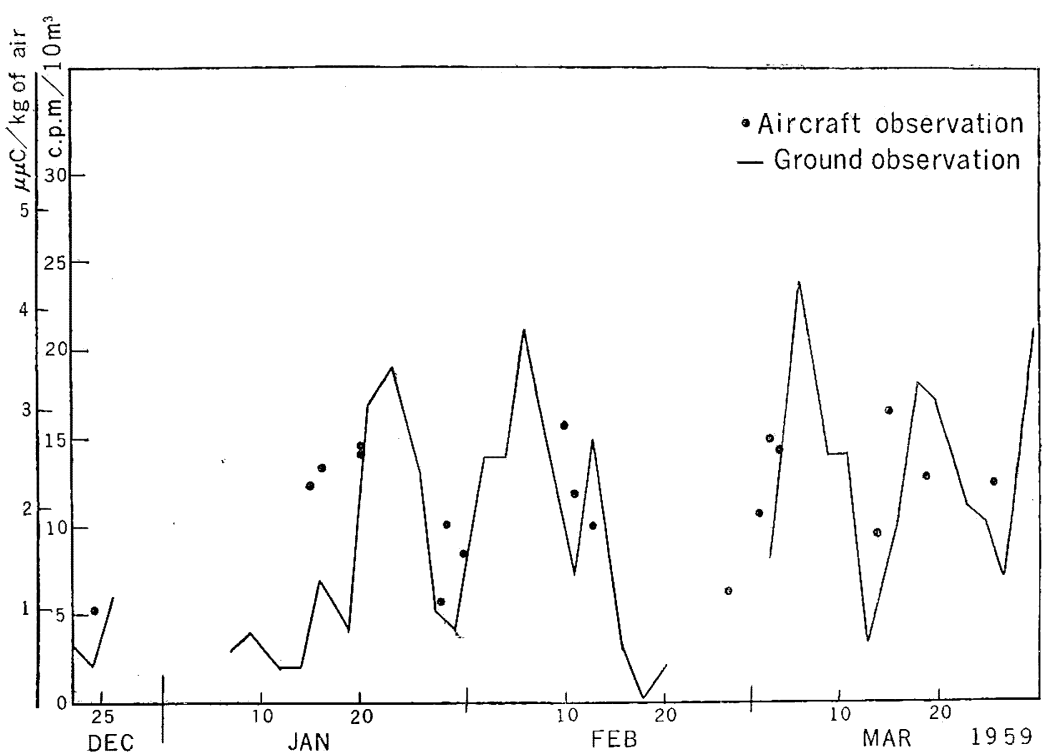

Fig. 5. The radioactivity of ground level (Tokyo) and $2000-3000 \mathrm{~m}$ above the ground.

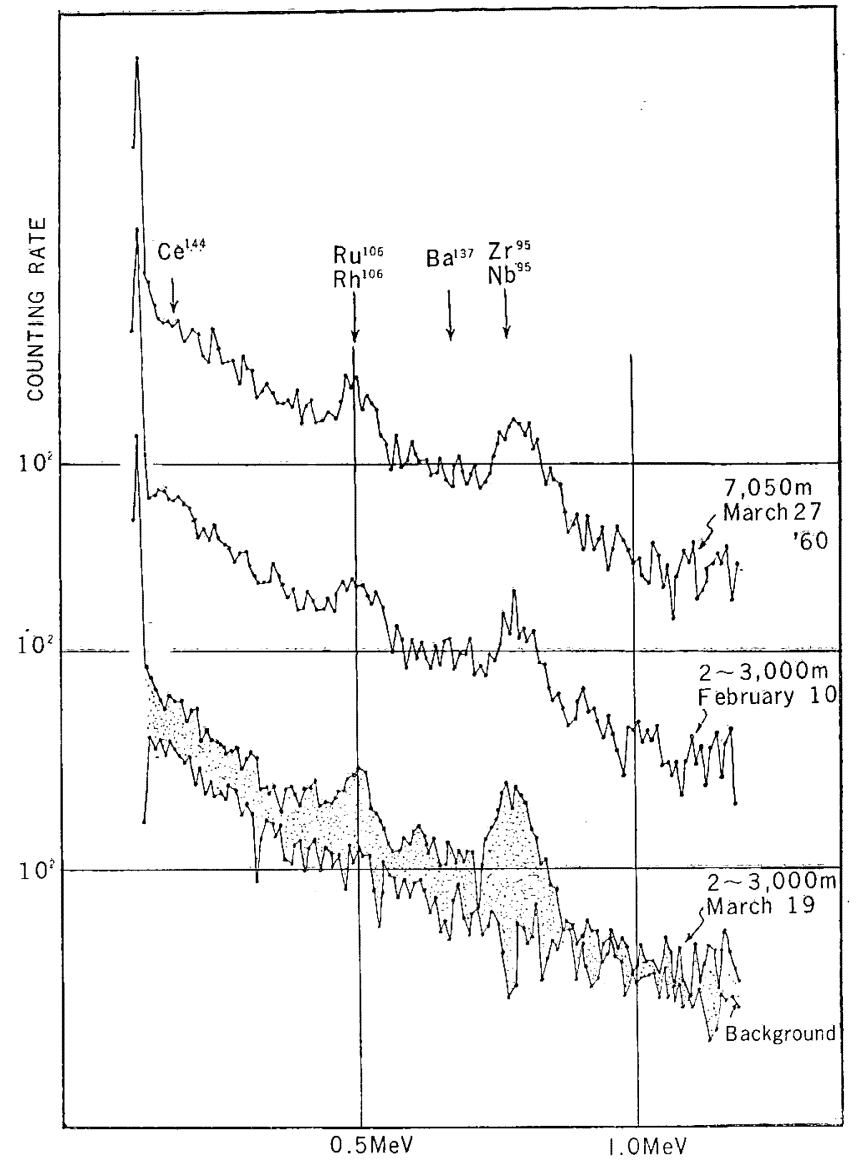

Fig. 6. $\quad \gamma$-energy spectrum for airborne dust. 


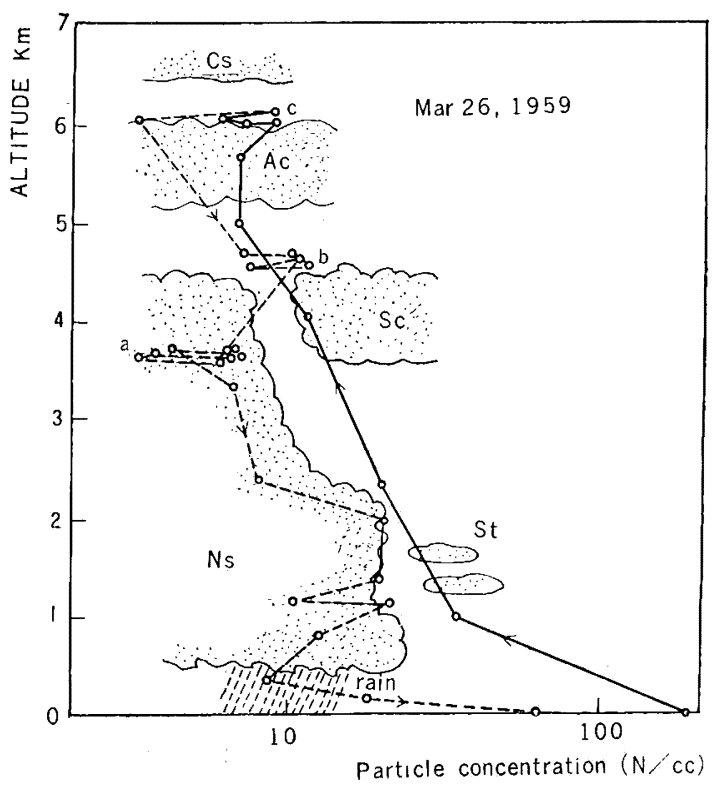

Fig. 7. Vertical concentration of the air-borne dust $>4 \mu$ in diameter.

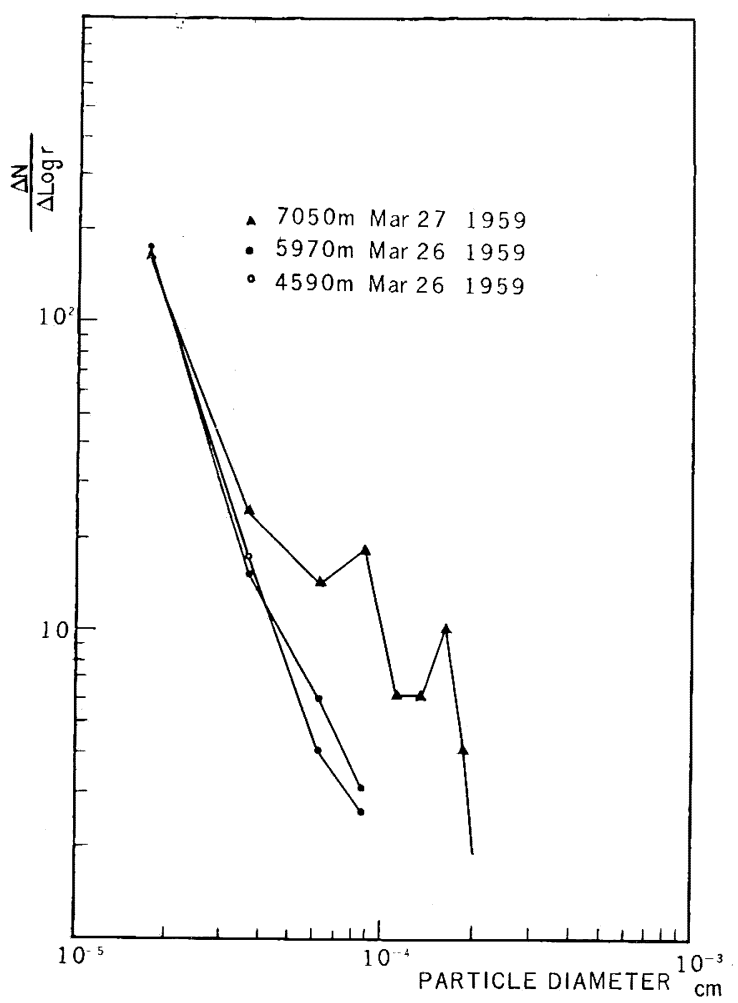

Fig. 8. Particle size distribution of three different altitude.
No comparison with decay curves for each altitude is demonstrated here, but all dècay coefficients are in good agreement within error of measurement.

b) Analysis of airborne dust particles.

The particle concentration of airborne dust was measured in the observation at each height on March 26 , when a front was at, or in the vicinity of, Japan and a bad weather condition widely covered almost the whole area of Japan. The results of this observation are illustrated in Fig. 7 , in which abscissas indicate the particle number per unit volume on the logarithmic scale and ordinates altitude. Solid lines show the particle concentration obtained in the ascending, dashed lines the particle concentration obtained in the descending of the aircraft. The particle concentration of larger size decreases exponentially with heights in a clear sky, but the concentration in clouds is more or less complicated, but the number of such larger-size particle markedly decreased when it is in the cloud. It is of interest to compare dust concentration at heights indicated by $a, b$ and $c$ in Fig. 7 with radioactivity shown in Fig. 4.

The particle size distributions of three different heights are given in Fig. 8. Samples at $7050 \mathrm{~m}$, as previously described, were collected on the day succeeding the sampling of other materials. On that day Japan was mainly crossed by the belt of anticyclones, and so the weather was fine. The distribution obeys 3 power low in general, but a lot of particles having diameters over the range $0.5-2 \mu$ was recognized on the distribution of samples at $7050 \mathrm{~m}$ (JUNGE,1958). The electronmicroscopic photograph of 


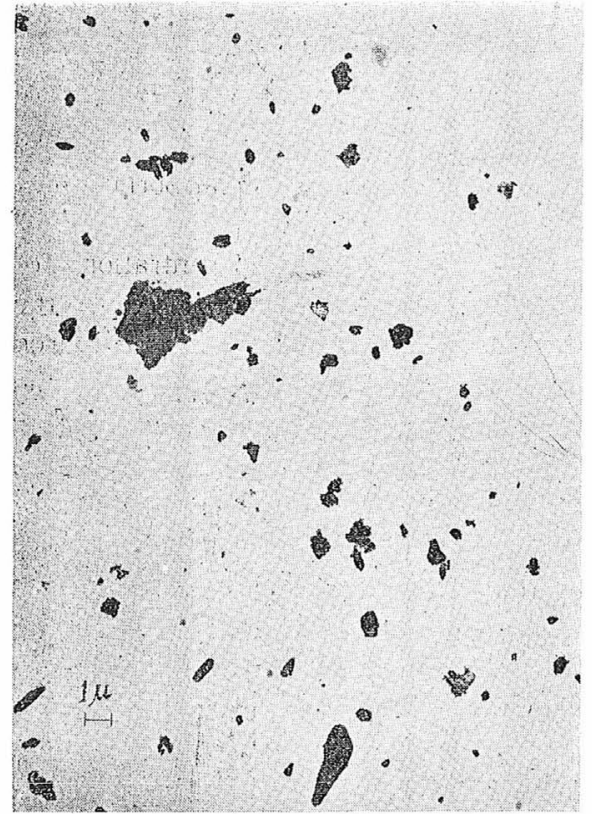

Fig. 9 Dust particle's photograph. 27th Mar. 1959 ( $\times 4000)$.

these particles is given in Fig.9. Electrone diffraction analysis shows that particles over this range are almost composed of soil matters.

\section{Discussien}

Hard difficulty lies in the determination of efficiency of each type of air sampler; even the filter method gives no truly reliable results. Seeing the ratios between radioactivity per $1 \mathrm{~kg}$ of air and atmospheric pressure, it is reasonable to consider that efficiency of the electrostatic precipitator is in proportion to the potential voltage. In fact, this efficiency is 70 percent of the efficiency of the filter paper method at 500$\mathrm{mb}$ level. Electrostatic efficiency would be $56 \%$ at $500 \mathrm{mb}$ level in the condition that the efficiency of filter paper has $80 \%$ for gear size particles.

It will be found from considerations on the diminution of efficiency that the radioactivity at $7,050 \mathrm{~m}$ height has values larger by about one order than values obtained on the ground on the same day (see Fig.4). The data obtained in foreign land make the same distribution of radioactivity up to $15 \mathrm{~km}$ height (Hvinden, 1957). Many previous reports state that the vertical distribution of radioactivity in the troposphere is highly subjected to washout effect due to precipitation (JMA, 1959), (YANO and NARUSE, 1956), (MiYake and Sugiura, 1951). In fact, the results of our observation show that the concentration of larger-size particles remarkably decreases in cloud. On the other hand, the particle numbers of airborne dust collected on the belt of anticyclones make a distribution which has peaks at about 1 diameter. It may be of much interest to note that these peaks would be in response to particles remaining suspensed in the stratosphere; such large particles wash out by raindrops after becoming condensation nuclei or colliding among raindrops.

Acknowledgements:- This investigation was conducted with the aid of funds supplied by the Science and Technics Agency and presented at the annual meeting of the Japan Radiation Research Society.

The authors wish to express their gratitude to the staff members of the Observation Division of Meteorological Agency for their invaluable help and also indebted to Dr. Hironcbu Watanabe and Assistant Professor, Tadayoshi Doke for previding us with equipments. 


\title{
References
}

Hvinden T. 1957: Radioactive Fallout in Norway.

Japan Meteorological Agency, 1956: Bulletin of the Atmospheric Radioactivity, No.6, Jan. March, Tokyo.

Junge C.E. 1958: Atmospheric Chemistry, pp. 7 9, Advances in Geophysics. Academic Press Inc. Publishers, New York.

Mryake Y. and Sugrura Y., 1951: The mechanism of dissolution of atmospheric chloride into rain water.

Morita K. and Fukui K. 1956: Variation of Radioactivity in Rain Water "Tenki" (in Japanese).

Peter Loysen, Alrred J. Brestin, Hugo. J. Drgiovanni 1956: Experimental Collection Efficiency of a Stratospheric Air Sampler. U.S. A. E.C. Report.

Rose H.E. and Woon A.J. 1956: An Introduction to Electrostatic Precipitation in Theory and Practice. Constable \& Company Ltd. London.

Stemart, N.G. R. N. Crooks and Miss E.M.R. Fisher 1957: The world-wide deposition of long lived fission products from nuclear test explosions. A. E. R. E. Mp/R 2354 Oct.

Yano N. and Naruse H., 1956: Artificial Radioactive Dust. " Research on the Effects and Influences of the Nuclear Bomb Test Explosions" Science Council of Japan 1956.

\section{対流圈内浮遊塵埃の放射能と粒子解析について}

\author{
矢 野 直, 成 瀬 弘
}

核爆発実験の影響を調查する目的で 上層大気中の浮遊塵埃の放射能新上びその 粒子解析を行つた 1957 年 5 月より 1959 年 3 月までに 28 回 1959 年 5 月より 1960 年 2 月まで 16 回の観測がおこなおれた 浮遊配埃は飛行機に取付けられた静電集麈器によつて比較的多量の空気中から採取された 採取飛行は東京

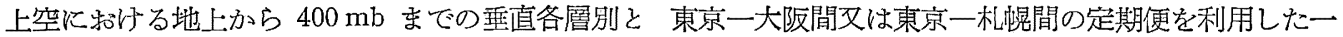
定高度で行われた

集塺器として使用した静電集塺器は採取空気量は大きいが 気圧による效率低下があり $500 \mathrm{mb}$ に招 いて約 $56 \%$ と推定される

浮遊鷹埃放射能の垂直分布はいずれも高度とともに指数函数的に増加が認められ 1959 年 3 月 27 日の 試料は $400 \mathrm{mb}$ に扔いて 集䖒勃率を考慮すれば地上の約 20 倍に達した この時期の試料を約半年後にガ ンマ線スペクトル分折した結果では $\mathrm{Rh}^{106}$ および $\mathrm{Zr}^{95}-\mathrm{Nb}^{95}$ の長寿命核種が認められた 定期便による試 料の放射能は東京に和ける地上の測定值と比較すると同様な变化傾向をもち 気団 気圧との相関がみられ た

比較的大きな粒子（半経 $2 \mu$ 以上）の粒子数濃度を各層別採取試料についてみると降雨中あるいは雲 中で著しく減少して和り 睛天の日に $400 \mathrm{mb} て ゙$ 取られた試料には普通この高度ではみられない多量の大き な粒子(半経約 $1 \mu$ ) が認められた 